\title{
The lichen genus Xanthoparmelia (Parmeliaceae) in Belarus
}

\author{
Andrei Tsurykau ${ }^{1,2}$, Vladimir Golubkov ${ }^{3} \&$ Pavel Bely $^{4}$ \\ ${ }^{1}$ Department of Biology, F. Skorina Gomel State University, Sovetskaja Str. 104, BY-246019 Gomel, Belarus. \\ E-mail: tsurykau@gmail.com \\ ${ }^{2}$ Department of Ecology, Botany and Nature Protection, Institute of Natural Sciences, Samara National Research \\ University, Moskovskoye road 34, RU-443086 Samara, Russia \\ ${ }^{3}$ Laboratory of Mycology, V.F. Kuprevich Institute of Experimental Botany of the National Academy of Sciences of the \\ Republic of Belarus, Akademicheskaja Str. 27, BY-220072 Minsk, Belarus. E-mail: vgolubkov@tut.by \\ ${ }^{4}$ Laboratory of Ecological Physiology of Plants, Central Botanical Garden of the National Academy of Sciences of the \\ Republic of Belarus, Surganova 2B, BY-220012 Minsk, Belarus. E-mail: pavel.bely@tut.by
}

\begin{abstract}
Two hundred six specimens of Xanthoparmelia collected in Belarus in 1905-2017 were examined based on morphological and chemical characters. Six species (X. angustiphylla, X. conspersa, X. delisei, X. loxodes, X. pulla and X. verruculifera) were identified in this study. Xanthoparmelia angustiphylla and $X$. delisei are reported for Belarus for the first time. Presence of Xanthoparmelia pokornyi and X. stenophylla has not been confirmed, and therefore these species should be excluded from the Belarusian list of lichens. A key to the species of Xanthoparmelia in Belarus is provided.
\end{abstract}

Keywords: biodiversity, secondary metabolites, chemotaxonomy, ecology

\section{INTRODUCTION}

The genus Xanthoparmelia (Vain.) Hale (Parmeliaceae) is the largest genus of foliose lichens with over 800 accepted species worldwide (Blanco et al., 2004). Most species are distributed in the Southern Hemisphere and confined to subtropical areas, and only 34 species are known in Europe (Hale, 1990; Giordani et al., 2002; Hawksworth et al., 2008; 2011; Kanigowski et al., 2016).

So far six species have been reported in Belarus, namely Xanthoparmelia conspersa (Ehrh. ex Ach.) Hale, X. loxodes (Nyl.) O. Blanco et al., X. pulla (Ach.) O. Blanco et al., X. pokornyi (Körb.) O. Blanco et al., X. stenophylla (Ach.) Ahti \& D. Hawksw. and $X$. verruculifera (Nyl.) O. Blanco et al. (Kreyer, 1913; Bachmann \& Bachmann, 1920; Golubkov, 1992; Golubkov \& Yesis, 1997; Hawksworth et al., 2008). However, the chemical variation of the Xanthoparmelia species was neglected in most of these papers as thin layer chromatography (TLC) has not been applied, although chemical traits play the most important role during species identification (Culberson et al., 1977; Esslinger, 1977; Hale, 1990; Szczepańska \& Kossowska, 2014). Recently, some lichen genera were revised in Belarus with the aid of TLC (Bely et al., 2014; Tsurykau \& Golubkov, 2015; Tsurykau et al., 2015; 2016) revealing 12 species new to the country and re-estimating distribution of lichens which are red-listed and protected by law in Belarus. In this paper we present the results of the revision of the lichen genus Xanthoparmelia in Belarus.

\section{MATERIAL AND METHODS}

This study is based on material in GSU, MSK, MSKH, MSKU and LE herbaria (Thiers, [continuously updated]). Morphological traits were studied under a stereomicroscope, Nikon SMZ745 , and secondary lichen compounds were studied by means of thin layer chromatography in solvent system $\mathrm{C}$ according to the methods of Orange et al. (2001). When more than one species was present in a packet, each taxon was counted as a separate specimen. Duplicates were counted as one specimen.

\section{RESULTS}

Two hundred six samples collected in Belarus in 1905-2017 were studied and six species were recorded in the examined material, namely Xanthoparmelia angustiphylla (Gyeln.) Hale, $X$. conspersa, X. delisei (Duby) O. Blanco et al., $X$. loxodes, $X$. pulla and $X$. verruculifera, of which $X$. angustiphylla and $X$. delisei are new to the country. 
No samples of Xanthoparmelia pokornyi and X. stenophylla were identified in the Belarusian material. The single report of Xanthoparmelia pokornyi by Hawksworth et al. (2008) is erroneous (Ahti, pers. comm.), and therefore the species should be excluded from the Belarusian list of lichens. Xanthoparmelia stenophylla was firstly reported by Golubkov (1992) as Parmelia taractica Kremp., and later as Xanthoparmelia molliuscula (Ach.) Hale (Golubkov, 1996). Recently, the species was additionally reported for Berezinsky Biosphere Reserve by Bely \& Golubkov (2012) as X. somloënsis (Gyeln.) Hale. All these samples contained stictic acid complex and norstictic acid, and belonged to $X$. angustiphylla. The report of $X$. stenophylla by Yatsyna (2009) cannot be accepted here as it was not accompanied by chemical and distributional data, and we did not get access to this sample in KW.

\section{THE SPECIES}

Xanthoparmelia angustiphylla (Gyeln.) Hale, Mycotaxon 33: 401 (1988).

Morphology. The species is characterized by adnate rosette thallus up to $5 \mathrm{~cm}$ in diameter. Lobes elongate, slightly overlapping, up to 2 $\mathrm{mm}$ wide. Upper surface yellowish green, matt or shiny. Lower surface black at least in central parts, bearing simple rhizines. Soralia and isidia absent. Apothecia found in one specimen up to $6 \mathrm{~mm}$ in diameter.

Chemistry. Usnic acid in the cortex; constictic, cryptostictic, norstictic and stictic acids in the medulla.

Habitat. Xanthoparmelia angustiphylla inhabits siliceous stones in well-lit situations.

Distribution in Belarus and neighbouring countries. New to Belarus. Xanthoparmelia angustiphylla is a rare species (Fig. 1A), recorded in four localities in Grodno and Minsk regions. Among the neighboring countries, the species was reported only from Poland (Kanigowski et al., 2016).

Notes. Twenty-one Xanthoparmelia species with yellowish thalli, i.e. containing usnic acid, are known in Europe (Giordani et al., 2002; PérezVargas et al., 2007; Hawksworth et al., 2008; 2011; Kanigowski et al., 2016). Of these, six species have the same medullary chemistry as
X. angustiphylla (see Hale, 1990; Crespo et al., 2001), but those taxa differ in thallus morphology, having either isidia or soralia; only X. cumberlandia (Gyeln.) Hale and X. vicentii A. Crespo et al. are also without any vegatative propagules, but these species differ in having pale brown to brown lower surface and branched and tufted at the apices, not simple rhizines, respectively (Crespo et al., 2001; Giordani et al., 2002; Kanigowski et al., 2016).

In Belarus, only one herbarium sample was mislabelled as $X$. conspersa while the others were incorrectly identified as $X$. somloënsis and X. stenophylla (Golubkov, 1992; Bely \& Golubkov, 2012).

Number of specimens examined -4 .

Material examined. Grodno region, Grodno district, close to Kvasovka village, $53^{\circ} 30^{\prime} \mathrm{N}, 23^{\circ} 59^{\prime} \mathrm{E}$, on stone, 01.07.2004, Rogovsky (MSK-L); Shchuchin district, close to Sviridy village, $53^{\circ} 41^{\prime} \mathrm{N}, 24^{\circ} 50^{\prime} \mathrm{E}$, on stone, 02.06.1999, V. Golubkov (MSK-L); Minsk region, Borisov district, close to Selets village, $54^{\circ} 36^{\prime} \mathrm{N}, 28^{\circ} 37^{\prime} \mathrm{E}$, on stone, 27.05.2008, P. Bely (MSKH); Miadzel district,
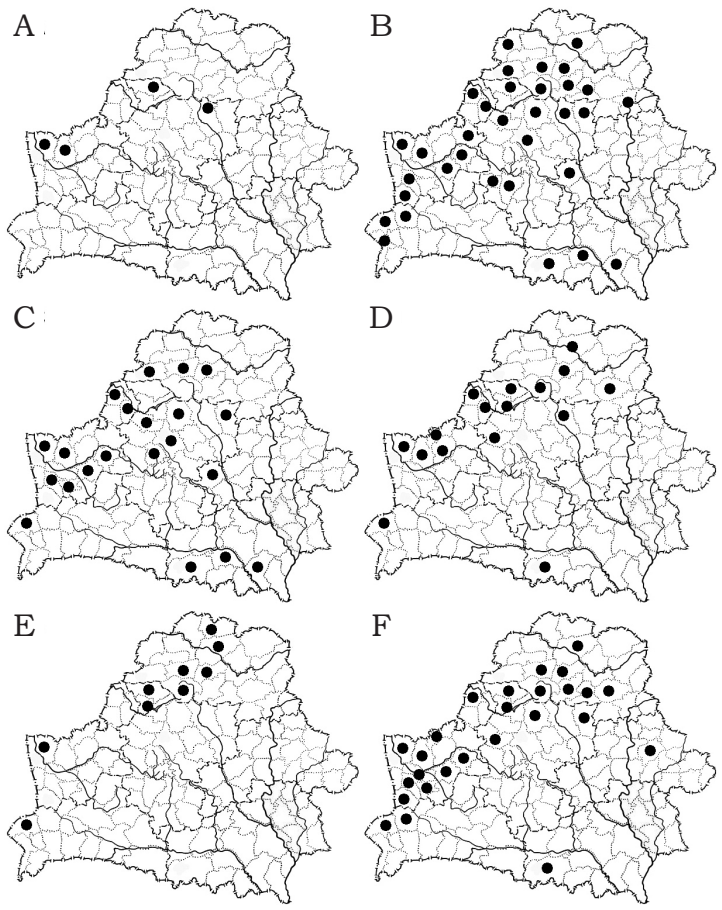

Fig. 1. Distribution of Xanthoparmelia angustiphylla (A), X. conspersa (B), X. delisei (C), $X$. loxodes (D), X. pulla (E) and $X$. verruculifera $(\mathrm{F})$ in Belarus. 
close to Naroch lake, on stone, 23.07.1946, N. O. Tsetterman (MSKU).

Xanthoparmelia conspersa (Ehrh. ex Ach.) Hale, Phytologia 28 (5): 485 (1974).

Morphology. Thallus adnate, up to $15 \mathrm{~cm}$ in diameter. Lobes elongate, often overlapping, up to $2 \mathrm{~mm}$ wide. Upper surface yellowish green, dark in central parts smooth or shiny. Lower surface black, pale brown to brown at the lobe margins, shiny, with simple rhizines. Soralia absent. Isidia laminal, cylindrical, simple to coralloid. Pycnidia common, immersed. Apothecia rare, up to $1 \mathrm{~cm}$ in diameter

Chemistry. Usnic acid in the cortex; constictic, cryptostictic, norstictic and stictic acids in the medulla.

Habitat. In Belarus Xanthoparmelia conspersa has been found on siliceous stones (granite, gneiss etc.) mainly in open localities, rarely in Scots pine and silver birch forests. One sample was collected from plant debris.

Distribution in Belarus and neighbouring countries. Xanthoparmelia conspersa is the most widely distributed and commonest species in the country ( $36.4 \%$ of the studied specimens) being known from all regions of Belarus. As most saxicolous lichens in Belarus (Golubkov, 1992; 1996), the species is most frequent in the northwestern part of the country (Fig. 1B). We associate this with the concentration of boulder material of glacial origin that entered the study area during the Pleistocene together with the Scandinavian glaciers (Makhnach, 2004). The last glacier did not reach southern Belarus (territories of the Belarusian Polesie) and therefore lack of suitable substrata is considered to be the main limiting factor in distribution of saxicolous lichens on those areas.

Xanthoparmelia conspersa was reported from all neighbouring Belarus countries (Kondratyuk et al., 2010; Urbanavichus, 2010; Ābolina et al., 2015; Kanigowski et al., 2016; Motiejūnaite, 2017).

Notes. The species is chemically identical to $X$. angustiphylla but differs by forming isidia (Table 1). Nevertheless, some juvenile thalli of $X$. conspersa can be confused with the former species (see also Kanigowski et al., 2016). In Europe, only two other Xanthoparmelia species have the same medullary chemistry and form isidia, namely $X$. isidiovagans $O$. Blanco et al. and $X$. plittii (Gyeln.) Hale. Of these, the former has vagrant life habit while the latter differs by pale lower surface (Hale, 1990; Blanco et al., 2005).

Number of specimens examined - 75 .

Selected material examined. Brest region, Kamenets district, Belovezhskaja Puscha National Park, 0.3 $\mathrm{km}$ SE Kamenjuki village, $52^{\circ} 33^{\prime} \mathrm{N}, 23^{\circ} 47^{\prime} \mathrm{E}$, sandy wasteland with Corynephorus canescens, on granite stone, 08.06.1983, V. Golubkov (MSK-L); Gomel region, Mozyr district, close to Strelsk village, $51^{\circ} 57^{\prime} \mathrm{N}$, $29^{\circ} 24^{\prime} \mathrm{E}$, on "Stone oxen" boulder, 19.08.1977, V. Golubkov (MSKU 1073); Grodno region, Grodno district, 8th forth of the Grodno fortress, $2 \mathrm{~km} \mathrm{SE}$ of the city of Grodno, close to Gibulichi village, $53^{\circ} 36^{\prime} \mathrm{N}, 23^{\circ} 51^{\prime} \mathrm{E}$, on granite stone, 29.10.2007, V. Golubkov (MSK-L); Minsk region, Logoisk district, $2 \mathrm{~km} \mathrm{SE}$ of Pleschenitsy village, $54^{\circ} 24^{\prime} \mathrm{N}, 27^{\circ} 51^{\prime} \mathrm{E}$, on boulder, 19.06.1956, N. V. Gorbach (MSK-L 7517); Mogilev region, Osipovichi district, close to Britsalovichi village, $53^{\circ} 22^{\prime} \mathrm{N}, 28^{\circ} 49^{\prime} \mathrm{E}$, on stone, 21.05.2004, A. Yatsyna (MSKU); Vitebsk region, Dokshitsy district, $0.5 \mathrm{~km} \mathrm{SW}$ of Budilovka village, $54^{\circ} 47^{\prime} \mathrm{N}, 27^{\circ} 58^{\prime} \mathrm{E}$, on granite stone, 16.09.2015, P. Bely (MSKH).

Xanthoparmelia delisei (Duby) O. Blanco, A. Crespo, Elix, D. Hawksw. \& Lumbsch, Taxon 53 (4): 967 (2004).

Morphology. Thallus rosette, adnate, up to $7 \mathrm{~cm}$ in diameter. Lobes elongate, up to $3 \mathrm{~mm}$ wide. Upper surface yellowish brown to dark brown, rarely covered by pruina, smooth. Lower surface black, pale brown to brown at the lobe margins, with simple rhizines. Soralia and isidia absent. Pycnidia common, immersed. Apothecia rare, sessile to stipitate, up to $2 \mathrm{~cm}$ in diameter.

Chemistry. Glomellic, glomelliferic, perlatolic and occasionally gyrophoric acid (3 samples, or $8.3 \%)$ in the medulla; atranorin in the cortex (7 samples, or $19.4 \%$ ).

Habitat. Xanthoparmelia delisei usually grows in dry, open and well-lit places on siliceous erratic boulders and stones on the roadsides, fields, meadows, and rarely at the Scots pine (Pinus sylvestris L.) and pedunculate oak (Quercus robur L.) forest edges.

Distribution in Belarus and neighbouring countries. New to Belarus. Xanthoparmelia delisei is a widespread lichen species in northwestern Belarus. Recent revision sufficiently extended the knowledge about ecology and distribution of this species in Poland (Szczepańska \& Kossowska, 2014) where it had been previously 
Table 1. Chemical and morphological traits of the Xanthoparmelia species in Belarus and neighbouring countries: Latvia (Āboliņa et al., 2015), Lithuania (Motiejūnaitè, 2017), Poland (Szczepańska \& Kossowska, 2014; Kanigowski et al., 2016), Russia ${ }^{1}$ (Urbanavicius, 2010) and Ukraine $^{2}$ (Kondratyuk et al. 1998)

\begin{tabular}{|c|c|c|c|c|c|c|c|}
\hline \multirow[t]{2}{*}{ Species } & \multirow{2}{*}{$\begin{array}{l}\text { Life } \\
\text { habit }\end{array}$} & \multirow{2}{*}{$\begin{array}{l}\text { Major medullary sec- } \\
\text { ondary metabolites }\end{array}$} & \multicolumn{4}{|c|}{ Morphological diagnostic characters } & \multirow[t]{2}{*}{ Distribution } \\
\hline & & & isidia & soredia & $\begin{array}{l}\text { upper } \\
\text { surface }\end{array}$ & $\begin{array}{l}\text { lower } \\
\text { surface }\end{array}$ & \\
\hline $\begin{array}{l}X \text {. angustiphylla } \\
\text { (Gyeln.) Hale }\end{array}$ & adnate & $\begin{array}{l}\text { norstictic and stictic } \\
\text { acids }\end{array}$ & absent & absent & $\begin{array}{l}\text { yellowish } \\
\text { green }\end{array}$ & black & Belarus, Poland \\
\hline $\begin{array}{l}\text { X. camtschadalis } \\
\text { (Ach.) Hale }\end{array}$ & vagrant & $\begin{array}{l}\text { salazinic and con- } \\
\text { salazinic acids }\end{array}$ & absent & absent & $\begin{array}{l}\text { yellowish } \\
\text { green }\end{array}$ & $\begin{array}{l}\text { pale } \\
\text { brown } \\
\text { to } \\
\text { brown }\end{array}$ & Russia \\
\hline $\begin{array}{l}X \text {. conspersa (Ehrh. ex } \\
\text { Ach.) Hale }\end{array}$ & adnate & $\begin{array}{l}\text { norstictic and stictic } \\
\text { acids }\end{array}$ & present & absent & $\begin{array}{l}\text { yellowish } \\
\text { green }\end{array}$ & black & $\begin{array}{l}\text { Belarus, Latvia, Lithu- } \\
\text { ania, Poland, Russia, } \\
\text { Ukraine }\end{array}$ \\
\hline $\begin{array}{l}\text { Xanthoparmelia } \\
\text { aff. cumberlandia } \\
\text { (Gyeln.) Hale }\end{array}$ & adnate & $\begin{array}{l}\text { norstictic and stictic } \\
\text { acids }\end{array}$ & absent & absent & $\begin{array}{l}\text { yellowish } \\
\text { green }\end{array}$ & $\begin{array}{l}\text { pale } \\
\text { brown } \\
\text { to } \\
\text { brown }\end{array}$ & Poland \\
\hline $\begin{array}{l}X \text {. delisei (Duby) O. } \\
\text { Blanco et al. }\end{array}$ & adnate & $\begin{array}{l}\text { glomelliferic and glo- } \\
\text { mellic acids }\end{array}$ & absent & absent & brown & black & Belarus, Poland \\
\hline $\begin{array}{l}X . \text { loxodes (Nyl.) O. } \\
\text { Blanco et al. }\end{array}$ & adnate & $\begin{array}{l}\text { glomelliferic and glo- } \\
\text { mellic acids }\end{array}$ & present & absent & brown & black & $\begin{array}{l}\text { Belarus, Latvia, Lithu- } \\
\text { ania, Poland }\end{array}$ \\
\hline $\begin{array}{l}\text { X. mougeotii (Schaer. } \\
\text { ex D. Dietr.) Hale }\end{array}$ & adnate & $\begin{array}{l}\text { norstictic and stictic } \\
\text { acids }\end{array}$ & absent & present & $\begin{array}{l}\text { yellowish } \\
\text { green }\end{array}$ & black & $\begin{array}{l}\text { Lithuania, Latvia, } \\
\text { Poland }\end{array}$ \\
\hline $\begin{array}{l}X . \text { plittii (Gyeln.) } \\
\text { Hale }\end{array}$ & adnate & $\begin{array}{l}\text { norstictic and stictic } \\
\text { acids }\end{array}$ & present & absent & $\begin{array}{l}\text { yellowish } \\
\text { green }\end{array}$ & $\begin{array}{l}\text { pale } \\
\text { brown } \\
\text { to } \\
\text { brown }\end{array}$ & Lithuania, Poland \\
\hline $\begin{array}{l}\text { X. protomatrae } \\
\text { (Gyeln.) Hale }\end{array}$ & adnate & $\begin{array}{l}\text { fumarprotocetraric } \\
\text { acid }\end{array}$ & absent & absent & $\begin{array}{l}\text { yellowish } \\
\text { green }\end{array}$ & $\begin{array}{l}\text { pale } \\
\text { brown } \\
\text { to } \\
\text { brown }\end{array}$ & Ukraine \\
\hline $\begin{array}{l}\text { X. pulla (Ach.) O. } \\
\text { Blanco et al. }\end{array}$ & adnate & divaricatic acid & absent & absent & brown & black & $\begin{array}{l}\text { Belarus, Latvia, Lithu- } \\
\text { ania, Poland, Russia, } \\
\text { Ukraine }\end{array}$ \\
\hline $\begin{array}{l}\text { X. stenophylla (Ach.) } \\
\text { Ahti \& D. Hawk- } \\
\text { sw. }\end{array}$ & adnate & $\begin{array}{l}\text { salazinic and con- } \\
\text { salazinic acids }\end{array}$ & absent & absent & $\begin{array}{l}\text { yellowish } \\
\text { green }\end{array}$ & $\begin{array}{l}\text { pale } \\
\text { brown } \\
\text { to } \\
\text { brown }\end{array}$ & $\begin{array}{l}\text { Lithuania, Latvia, Po- } \\
\text { land, Russia, Ukraine }\end{array}$ \\
\hline $\begin{array}{l}X . \text { tinctina (Maheu } \\
\text { \& A. Gillet) Hale }\end{array}$ & adnate & $\begin{array}{l}\text { salazinic, consalazinic } \\
\text { and norstictic acids }\end{array}$ & present & absent & $\begin{array}{l}\text { yellowish } \\
\text { green }\end{array}$ & black & Latvia, Ukraine \\
\hline $\begin{array}{l}\text { X. verruculifera (Nyl.) } \\
\text { O. Blanco et al. }\end{array}$ & adnate & divaricatic acid & present & absent & brown & black & $\begin{array}{l}\text { Belarus, Latvia, Lithu- } \\
\text { ania, Poland, Russia, } \\
\text { Ukraine }\end{array}$ \\
\hline
\end{tabular}

${ }^{1}$ Central part of European Russia (Ec) according to Urbanavicius (2010)

${ }^{2}$ Central European broad-leaved forest province (A) of Ukraine according to Kondratyuk et al. (1998)

considered an extremely rare species. Regarding other neighbouring countries, $X$. delisei is known only from Russia (Urbanavichus, 2010), but it is expected to be found in Lithuania and Latvia as it has been collected close to the state borders (Fig. 1C).
Notes. Lichens with brown thalli and upper cortex stained by $\mathrm{HNO}_{3}$ to blue-green are currently included to Xanthoparmelia pulla group, which comprises 13 species occurring in Europe (Hawksworth et al., 2008). Of these, only X. delisei, X. loxodella (Essl.) O. Blanco et al. and X. 
loxodes contain glomellic and glomelliferic acids while the other species differ in the content of secondary metabolites in thalli. Xanthoparmelia loxodella and $X$. loxodes clearly differ from $X$. delisei by forming isidia. Furthermore, $X$. loxodella produces additionally loxodellic rather than perlatolic acid.

In Belarus, all specimens of $X$. delisei were originally identified as $X$. pulla. Although the latter species can be sometimes recognized by its darker thallus and narrower lobes (Esslinger, 1977; Elix \& Thell, 2011), these features are ecologically variable and therefore TLC is strongly recommended to distinguish both species.

Number of specimens examined - 36 .

Selected material examined. Brest region, Kamenets district, Belovezhskaja Puscha National Park, 0.3 $\mathrm{km}$ SE Kamenjuki village, $52^{\circ} 33^{\prime} \mathrm{N}, 23^{\circ} 47^{\prime} \mathrm{E}$, sandy wasteland with Corynephorus canescens, on granite stone, 08.06.1983, V. Golubkov (MSK-L); Gomel region, Mozyr district, close to Strelsk village, $51^{\circ} 57^{\prime} \mathrm{N}$, $29^{\circ} 24^{\prime} \mathrm{E}$, on "Stone oxen" boulder, 19.08.1977, V. Golubkov (MSKU 1073); Grodno region, Grodno district, the city of Grodno, Southern micro-district, $53^{\circ} 36^{\prime} \mathrm{N}$, $23^{\circ} 49^{\prime} \mathrm{E}$, on granite stone, 27.06.1997, V. Golubkov (MSK-L); Minsk region, Krupki district, $1 \mathrm{~km} \mathrm{SW}$ of Lutyje village, $54^{\circ} 28^{\prime} \mathrm{N}, 29^{\circ} 16^{\prime} \mathrm{E}$, on granite stone, 15.09.1995, V. Golubkov (MSK-L); Mogilev region, Osipovichi district, close to Sloboda village, $53^{\circ} 25^{\prime} \mathrm{N}$, $28^{\circ} 57^{\prime} \mathrm{E}$, on stone, 21.05.2004, A. Yatsyna (MSKU $776,777,783)$; Vitebsk region, Ushachi district, $1 \mathrm{~km}$ W Krasnoje village, Berezovskoje lake area, $55^{\circ} 13^{\prime} \mathrm{N}$, $28^{\circ} 59^{\prime} \mathrm{E}$, on granite stone, 09.06.1990, V. Golubkov (MSK-L).

Xanthoparmelia loxodes (Nyl.) O. Blanco, A. Crespo, Elix, D. Hawksw. \& Lumbsch, Taxon 53 (4): 968 (2004).

Morphology. Thallus rosette, adnate, up to 8.5 $\mathrm{cm}$ in diameter. Lobes elongate, often overlapping, up to $3 \mathrm{~mm}$ wide. Upper surface yellowish brown to dark brown, smooth. Lower surface black, brown at the lobe margins, with simple rhizines. Soralia absent. Isidia laminal, globose, distinctly pustular eroding white medulla, clustered, up to $0.5 \mathrm{~mm}$ in diameter. Pycnidia rare, immersed. Apothecia rare, up to $3 \mathrm{~mm}$ in diameter.

Chemistry. Glomellic, glomelliferic, perlatolic and occasionally gyrophoric acid (3 samples, or $10.7 \%$ ) in the medulla; atranorin in the cortex (6 samples, or $21.4 \%$ ).

Habitat. Xanthoparmelia loxodes grows on siliceous glacier stones in well-lit open localities, rarely at forest edges. Single specimen was collected from wood on roof.

Distribution in Belarus and neighbouring countries. Xanthoparmelia loxodes is widespread in northwestern Belarus. It is currently considered as data deficient (DD) species in the recent edition of the Red Data Book of Belarus (Kachanovsky, 2015). Our revision has shown that most samples of this species were previously erroneously identified as $X$. verruculifera. In our opinion, this species should be excluded from the list of protected lichen species due to its frequency and distribution. Xanthoparmelia loxodes is known from all adjacent regions (Kondratyuk et al., 2010; Urbanavichus, 2010; Szczepańska \& Kossowska, 2014; Āboliṇa et al., 2015; Motiejūnaite, 2017).

Notes. In Belarus, the species can easily be confused with $X$. verruculifera, another isidioid member of $X$. pulla group. Both species can be separated by TLC as the latter contains divaricatic and stenosporic acids as major secondary metabolites. Although $X$. verruculifera has darker thalli, thinner lobes and smaller isidia (Elix \& Thell, 2011; Szczepańska \& Kossowska, 2014), the chemistry is the most important trait.

Number of specimens examined -28 .

Selected material examined. Brest region, Kamenets district, Belovezhskaja Puscha National Park, $0.3 \mathrm{~km}$ SE Kamenjuki village, $52^{\circ} 33^{\prime} \mathrm{N}, 23^{\circ} 47^{\prime} \mathrm{E}$, sandy wasteland with Corynephorus canescens, on granite stone, 08.06.1983, V. Golubkov (MSK-L); Gomel region, Lelchitsy district, Pripyatsky National Park, Mlynok forest, $51^{\circ} 56^{\prime} \mathrm{N}, 27^{\circ} 56^{\prime} \mathrm{E}$, on granite stone, 01.06.1974, O. P. Shakhrai (GSU); Grodno region, Smorgon district, $1.5 \mathrm{~km} \mathrm{~N}$ of Balobany village, $54^{\circ} 16^{\prime} \mathrm{N}, 26^{\circ} 16^{\prime} \mathrm{E}$, on granite stone, 16.06.1989, V. Golubkov (MSK-L); Minsk region, Volozhin district, close to Zabrezie village, $54^{\circ} 11^{\prime} \mathrm{N}, 26^{\circ} 27^{\prime} \mathrm{E}$, on granite stone, 18.10 .1988 , V. Golubkov (MSK-L); Vitebsk region, Dokshitsy district, $0.5 \mathrm{~km}$ SW of Budilovka village, $54^{\circ} 47^{\prime} \mathrm{N}, 27^{\circ} 58^{\prime} \mathrm{E}$, on granite stone, 16.09.2015, P. Bely (MSKH).

Xanthoparmelia pulla (Ach.) O. Blanco, A. Crespo, Elix, D. Hawksw. \& Lumbsch, Taxon 53 (4): 970 (2004).

Morphology. Thallus rosette, closely adnate, up to $6 \mathrm{~cm}$ in diameter. Lobes mainly flat, up to 3 $\mathrm{mm}$ wide. Upper surface brown to dark brown, rugose, rarely pruinose, dull. Lower surface black with simple rhizines. Soralia and isidia absent. Pycnidia common, immersed. Apothecia common, sessile to shortly stipitate, up to $8 \mathrm{~mm}$ in diameter. 
Chemistry. Stenosporic, divaricatic, perlatolic and gyrophoric acids in the medulla (all studied material); occasionally atranorin in the cortex (4 samples, $26.5 \%$ ).

Habitat. Xanthoparmelia pulla inhabits acidic stones in well-lit localities. One sample was collected at the Scots pine forest edge.

Distribution in Belarus and neighbouring countries. Xanthoparmelia pulla is the least common species within X. pulla group in Belarus. Most samples were re-identified during this revision and belonged to $X$. delisei. Currently, X. pulla is known mainly from 1946-1990, and only two samples were collected during last two decades. The species is extremely rare in Poland being confirmed from two localities only (Szczepańska $\&$ Kossowska, 2014). Xanthoparmelia pulla is also known from other neighbouring countries (Kondratyuk et al., 2010; Urbanavichus, 2010; Āboliņa et al., 2015; Motiejūnaité, 2017), but its true distribution is unclear as no revisions of herbarium material were done (Moisejevs, pers. comm.).

Notes. Currently, Xanthoparmelia pulla group includes 13 species occurring in Europe (Hawksworth et al., 2008). Of these, five species have similar medullary chemistry to X. pulla, but those taxa differ in thallus morphology by having pale brown lower surface of thallus or by forming isidia (Giordani et al., 2003; Amo de Paz et al., 2012). Xanthoparmelia perrugata is the most similar species to $X$. pulla, but it contains divaricatic acid as major chemical compound, while $X$. pulla produces stenosporic acid as major metabolite. Previously, both species were treated as two chemical races of $X$. pulla s. lat. (e.g. Coppins et al., 2002).

In Belarus, $X$. delise $i$ is the most similar species to $X$. pulla. Despite minor morphological differences (see Notes under $X$. delisei), the proper identification requires TLC.

Number of specimens examined - 15 .

Selected material examined. Brest region, Kamenets district, Belovezhskaja Puscha National Park, $0.3 \mathrm{~km}$ SE Kamenjuki village, $52^{\circ} 33^{\prime} \mathrm{N}, 23^{\circ} 47^{\prime} \mathrm{E}$, sandy wasteland with Corynephorus canescens, on granite stone, 08.06.1983, V. Golubkov (MSK-L); Grodno region, Grodno district, the city of Grodno, Pyshki forest park, pine forest edge, $53^{\circ} 41^{\prime} \mathrm{N}, 23^{\circ} 47^{\prime} \mathrm{E}$, on granite stone, 12.05.2007, O. M. Tretiakova (MSK-L); Minsk region, Miadel district, close to Yatsyny village, $54^{\circ} 58^{\prime} \mathrm{N}$, $27^{\circ} 14^{\prime} \mathrm{E}$, on granite stone, 09.08.1977, V. Golubkov
(MSKU 1074); Vitebsk region, Glubokoje district, 1.5 $\mathrm{km}$ E Plisa village, $55^{\circ} 12^{\prime} \mathrm{N}, 27^{\circ} 59^{\prime} \mathrm{E}$, on granite stone, 16.06.1996, V. Golubkov (MSK-L).

Xanthoparmelia verruculifera (Nyl.) O. Blanco, A. Crespo, Elix, D. Hawksw. \& Lumbsch, Taxon 53 (4): 972 (2004).

Morphology. Thallus rosette, adnate, to $8.5 \mathrm{~cm}$ in diameter. Lobes flat, short, up to $2 \mathrm{~mm}$ wide. Upper surface brown to dark brown, smooth. Lower surface black with simple rhizines. Soralia absent. Isidia laminal, globose, distinctly pustular eroding white medulla, clustered, up to $0.2 \mathrm{~mm}$ in diameter. Pycnidia rare, immersed. Apothecia rare, up to $1 \mathrm{~mm}$ in diameter.

Chemistry. Stenosporic, divaricatic and perlatolic acids, occasionally gyrophoric acid (22 samples, or $45.8 \%)$ in the medulla; atranorin in the cortex (18 samples, or $37.5 \%$ ).

Habitat. The species occurs in open and well-lit places on siliceous erratic boulders and stones on the roadsides, fields, meadows, and rarely at the Scots pine forest edges. One sample was found growing on wood.

Distribution in Belarus and neighbouring countries. Xanthoparmelia verruculifera is widespread in northwestern Belarus (Fig. 1F). The species is known from all adjacent regions (Kondratyuk et al., 2010; Urbanavichus, 2010; Szczepańska \& Kossowska, 2014; Āboliṇa et al., 2015; Motiejūnaitè, 2017).

Notes. Xanthoparmelia verruculifera clearly differs from other European members of X. pulla group containing divaricatic and stenosporic acids by forming isidia.

Number of specimens examined - 48 .

Selected material examined. Brest region, Kamenets district, Belovezhskaja Puscha National Park, $0.3 \mathrm{~km}$ SE Kamenjuki village, $52^{\circ} 33^{\prime} \mathrm{N}, 23^{\circ} 47^{\prime} \mathrm{E}$, sandy wasteland with Corynephorus canescens, on granite stone, 08.06.1983, V. Golubkov (MSK-L); Gomel region, Lelchitsy district, Pripyatsky National Park, Mlynok forest, $51^{\circ} 56^{\prime} \mathrm{N}, 27^{\circ} 56^{\prime} \mathrm{E}$, on granite stone, 01.06.1974, O. P. Shakhrai (GSU); Grodno region, Volkovysk district, $0.8 \mathrm{~km}$ SEE Pyataki village, $53^{\circ} 12^{\prime} \mathrm{N}, 2^{\circ} 27^{\prime} \mathrm{E}$, edge of pine wood, on granite stone, 03.08.2016, P. Bely (MSKH 6548); Minsk region, Logoisk district, 1 $\mathrm{km}$ E Shvaby village, $54^{\circ} 17^{\prime} \mathrm{N}, 28^{\circ} 10^{\prime} \mathrm{E}$, on granite stone, 01.07.1987, V. Golubkov (MSK-L); Mogilev region, Chausy district, $2 \mathrm{~km} \mathrm{NNE}$ of Chausy town, $53^{\circ} 50^{\prime} \mathrm{N}, 30^{\circ} 58^{\prime} \mathrm{E}$, on granite stone, 24.04.1990, V. Golubkov (MSK-L); Vitebsk region, Glubokoje district, $0.5 \mathrm{~km} \mathrm{E}$ of Prozorki village, $55^{\circ} 17^{\prime} \mathrm{N}, 28^{\circ} 13^{\prime} \mathrm{E}$, on granite stone, 14.06.1990, V. Golubkov (MSK-L). 


\section{Key to the species of Xanthoparmelia in Belarus}

1. Upper surface yellowish green, usnic acid

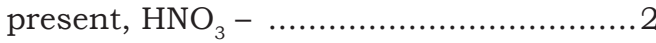

- Upper surface brown to dark brown, usnic acid absent, $\mathrm{HNO}_{3}+$ blue-green ..... 3

2. Isidia present ....................... conspersa

- Isidia absent ..................... angustiphylla

3. Isidia present...................................... 4

- Isidia absent .................................... 5

4. Upper surface pale brown to brown, lobes up to $3 \mathrm{~mm}$ wide, isidia up to $0.5 \mathrm{~mm}$ in diameter, glomellic and glomelliferic acids present ......................... X. loxodes

- Upper surface brown to dark brown, lobes up to $2 \mathrm{~mm}$ wide, isidia up to 0.2 $\mathrm{mm}$ in diameter, divaricatic acid present ................................ verruculifera

5. Upper surface pale brown to brown, glomellic and glomelliferic acids present... X. delisei

- Upper surface brown to dark brown, divaricatic acid present................. . pulla

\section{ACKNOWLEDGEMENTS}

We are grateful to Valentina Polyksenova and Svetlana Drobyshevskaja (Minsk) for providing access to the specimens housed in the MSKU herbarium, to Teuvo Ahti (Helsinki) for checking the earlier collections in $\mathrm{H}$, to Rolands Moisejevs (Daugavpils) for providing data about Xanthoparmelia species in Latvia, to Tiina Randlane (Tartu) and to an anonymous referee for their help and useful comments on the manuscript. The first author cordially thanks Julia V. Gerasimova and Sergei V. Chesnokov (both Saint Petersburg) for assistance during his work in LE.

\section{REFERENCES}

Āboliṇa, A., Piterāns, A. \& Bambe, B. 2015. Lichens and bryophytes in Latvia. Checklist. Salaspils. 213 pp.

Amo de Paz, G., Cubas, P., Crespo, A., Elix, J. A. \& Lumbsch, H. T. 2012. Transoceanic dispersal and subsequent diversification on separate continents shaped diversity of the Xanthoparmelia pulla group (Ascomycota). PLoS ONE 7(6): e39683. https://doi.org/10.1371/journal.pone.0039683

Bachmann, E. \& Bachmann, F. 1920. Litauishe Flechten. Hedwigia 61(6): 308-342.

Bely, P. N. \& Golubkov, V. V. 2012. Contribution to the lichen flora of the Berezinsky Biosphere Reserve (in Russian). Botany Research 41: 84-98.
Bely, P., Golubkov, V., Tsurykau, A. \& Sidorovich E. 2014. The lichen genus Cetrelia in Belarus: distribution, ecology and conservation. Botanica Lithuanica 20: 69-76. https://doi.org/10.2478/ botlit-2014-0010

Blanco, O., Crespo, A., Elix, J. A., Hawksworth, D. L. \& Lumbsch, H. T. 2004. A molecular phylogeny and a new classification of parmelioid lichens containing Xanthoparmelia-type lichenan (Ascomycota: Lecanorales). Taxon 53: 959-975. https://doi. org/ $10.2307 / 4135563$

Blanco, O., Crespo, A. \& Elix, J. A. 2005. Two new species of Xanthoparmelia (Ascomycota: Parmeliaceae) from Spain. Lichenologist 37: 97-100. https://doi.org/10.1017/S0024282905014829

Coppins, B. J., Seed, L. \& Earland-Bennett, P. M. 2002. Neofuscelia luteonotata, new to the British Isles, and notes to the N. pulla group. British Lichen Society Bulletin 90: 29-33.

Crespo, A., Molina, M. C. \& Elix, J. A. 2001. A new species of Xanthoparmelia (lichenized Ascomycotina, Parmeliaceae) from Spain. Mycotaxon 80: 363-366.

Culberson, C. F., Culberson, W. L. \& Esslinger, T. L. 1977. Chemosyndromic variation in the Parmelia pulla group. Bryologist 80: 125-135. https://doi. org/ $10.2307 / 3242518$

Elix, J. A. \& Thell, A. 2011. Xanthoparmelia. In: Thell, A. \& Moberg, R. (eds). Nordic Lichen Flora. Vol. 4. Parmeliaceae. Pp. 131-138.

Esslinger, T. L. 1977. A chemosystematic revision of the brown Parmeliae. Journal of Hattori Botanical Laboratory 42: 1-211.

Giordani, P., Nicora, P., Rellini, I., Brunialti G. \& Elix J. A. 2002. The lichen genus Xanthoparmelia (Ascomycotina, Parmeliaceae) in Italy. Lichenologist 34: 189-198. https://doi.org/10.1006/ lich.2002.0384

Giordani, P., Benesperi, R., Rellini, I., Frati, L., Brunialti, G., Paoli, L., Isocrono, D. \& Elix, J. A. 2003. The lichen genus Neofuscelia (Ascomycota, Parmeliaceae) in Italy. Lichenologist 35: 377-385. https://doi.org/10.1016/j.lichenologist.2003.09.001

Golubkov, V. V. 1992. Lichens of protected natural territories of Belarus (floristic and ecogeographical characteristic) (in Russian). Ph.D. thesis. Minsk. 503 pp.

Golubkov, V. V. 1996. Influence of anthropogenic transformation of landscapes on lichen distribution and diversity in the Belarusian Lakeland (in Russian). In: Dorofeev, A. M. (ed.). Biological conservation in Belarusian Lakeland: Abstracts of regional conference. Vitebsk. Pp. 81-82.

Golubkov, V. V. \& Yesis, S. M. 1997. Preliminary data on lichens from Minsk Upland (in Russian). In: Aleksandrovich, A.G. (ed.). Actual problems of natural sciences: Abstracts of the Jubilee Scientific Conference devoted to the 25th anniversary of the Department of Natural Sciences. Minsk. Pp. 66-73. 
Hale, M. E. 1990. A synopsis of the lichen genus Xanthoparmelia (Vainio) Hale (Ascomycotina, Parmeliaceae). Smithsonian Contributions to Botany 74: 1-250. https://doi.org/10.5479/si.0081024X.74

Hawksworth, D. L., Blanco, O., Divakar, P. K., Ahti T. $\&$ Crespo, A. 2008. A first checklist of parmelioid and similar lichens in Europe and some adjacent territories, adopting revised generic circumscriptions and with indications of species distributions. Lichenologist 4: 1-28. https://doi.org/10.1017/ S0024282908007329

Hawksworth, D. L., Divakar, P. K., Crespo, A. \& Ahti, T. 2011. The checklist of parmelioid and similar lichens in Europe and some adjacent territories: additions and corrections. Lichenologist 43: 639-645. https://doi.org/10.1017/ S0024282911000454

Kachanovsky, I. M. (ed.). 2015. Red Data Book of the Republic of Belarus: Rare and endangered species of wild plants. Plants. Minsk. 448 pp.

Kanigowski, P., Flakus, A., Oset, M., Kowalewska, A., Rykaczewki, M. \& Kukwa, M. 2016. The lichen family Parmeliaceae in Poland. Xanthoparmelia species containing usnic acid. Herzogia 29: 108-119. https://doi.org/10.13158/ heia.29.1.2016.108

Kondratyuk, S. Y., Dymytrova, L. V. \& Nadyeina, O. V. 2010. The third checklist of lichen-forming and allied fungi of Ukraine. In: Kondratyuk, S. Y. \& Roms, O. G. (eds). Flora Lišajnikiv Ukraini, Vol. 2, part 3. Kyiv. Pp. 446-486.

Kondratyuk, S. Y., Khodosovtsev, A. Y. \& Zelenko, S. D. 1998. The second checklist of lichen forming, lichenicolous and allied fungi of Ukraine. Kiev. $180 \mathrm{pp}$.

Kreyer, G. K. 1913. Contribution to lichen flora of Mogilev province. Collections of 1908-1910 (in Russian). Acta Horti Petropolitani 31: 263-440.

Makhnach, A. A. 2004. Introduction to geology of Belarus. Institute of Geological Sciences NASB, Minsk. 198 pp.

Motiejūnaitè, J. 2017. Supplemented checklist of lichens and allied fungi of Lithuania. Botanica
Lithuanica 23: 89-106. https://doi.org/10.1515/ botlit-2017-0011

Orange, A., James, P. W. \& White, F. J. 2001. Microchemical Methods for the Identification of Lichens. British Lichen Society, London. 101 pp.

Pérez-Vargas, I., Hernández-Padrón, C. \& Elix, J. A. 2007. A new species of Xanthoparmelia (Ascomycota: Parmeliaceae) from the Canary Islands. Lichenologist 39: 445-449. https://doi. org/10.1017/S0024282907007189

Szczepańska, K. \& Kossowska, M. 2014. The lichenforming fungi of the Xanthoparmelia pulla group (Parmeliaceae, Ascomycota) in Poland. Acta Societatis Botanicorum Poloniae 83: 59-65. https:// doi.org/10.5586/asbp.2014.004

Thiers, B. [continuously updated]. Index Herbariorum: A global directory of public herbaria and associated staff. New York Botanical Garden's Virtual Herbarium. http://sweetgum.nybg.org/ih/

Tsurykau, A. \& Golubkov, V. 2015. The lichens of the Cladonia pyxidata-chlorophaea complex in Belarus. Folia Cryptogamica Estonica 52: 63-71. https://doi.org/10.12697/fce.2015.52.08

Tsurykau, A., Golubkov, V. \& Bely, P. 2015. The genera Hypotrachyna, Parmotrema and Punctelia (Parmeliaceae, lichenized Ascomycota) in Belarus. Herzogia 28: 736-745. https://doi.org/10.13158/ heia.28.2.2015.736

Tsurykau, A., Golubkov, V. \& Bely, P. 2016. The genus Lepraria (Stereocaulaceae, lichenized Ascomycota) in Belarus. Folia Cryptogamica Estonica 53: 43-50. https:/ / doi.org/10.12697/fce.2016.53.06

Urbanavichus, G. P. 2010. A checklist of the lichen flora of Russia (in Russian). St. Petersburg. 194 pp.

Yatsyna, A. P. 2009. Preliminary results and prospects of the inventory of Belarusian lichen specimens in the herbarium of the M. G. Kholodny Institute of Botany of NAS of Ukraine (in Russian). In: Kordyum, E. L. (ed.) Actual problems of botany and ecology: Abstracts of International conference of young scientists. Ternopil. Pp. 90-91. 